This is an author produced version of a paper published in WORK : A Journal of Prevention, Assessment, and Rehabilitation. This paper has been peer-reviewed but does not include the final publisher proof-corrections or journal pagination.

Citation for the published paper:

Norstedt, Maria. (2017). The (im)possibilities of returning to work after a stroke. WORK : A Journal of Prevention, Assessment, and Rehabilitation, vol. 56 , issue 4 , p. null

URL: https://doi.org/10.3233/WOR-172521

Publisher: IOS

This document has been downloaded from MUEP (https://muep.mah.se) / DIVA (https://mau.diva-portal.org). 


\section{The (Im)possibilities of Returning to Work After a Stroke}

Maria Norstedt, Malmö University, Malmö, Sweden.

Abstract

BACKGROUND: What a stroke means for working-age persons has not been sufficiently studied from a sociological perspective.

OBJECTIVE: This article uses the empirical material of a larger study to describe and analyze how institutional practices and discourses influence attempts to return to work after a stroke.

METHODS: Semi-structured interviews were conducted with ten persons who have had a stroke and ten civil servants and professionals from the Swedish Public Employment Service, the Social Insurance Agency, and different health care institutions. The qualitative analysis was inspired by institutional ethnography.

RESULTS: The analysis shows how persons who have had a stroke and civil servants and professionals in welfare organizations share the same goal: a return to working life for the former. The persons in this study related to, translated, and put into practice discourses of normality and employability in this process. However, there were, at times, conflicting institutional practices between the different organizations.

CONCLUSIONS: Conflicting institutional practices connected to the discourses of normality and employability contribute to the 
difficulties that persons who have had a stroke face when trying to return to work after recovery.

Keywords: Swedish welfare state, normality, employability, workability, the work strategy (arbetslinjen)

\section{Introduction}

Stroke is one of the most common causes of death and disability in Sweden. Every year, 30,000 people are affected. As nearly $20 \%$ of the persons who have had a stroke are younger than 65 years of age, and the proportion of persons under that age has increased in later years, research on return to work is urgent $[1,2]$. Both research and public statistics in Sweden indicate that only about half of those who were working before their stroke returned to work $[1,3]$. For many, having a stroke means both a psychological trauma and a total change in life. A stroke can lead to both visible and hidden impairments such as "weakness on one side of the body typically affecting the upper limb (77\% of survivors), urinary incontinence (48\%), impaired consciousness (45\%), dysphagia (45\%), and impaired cognition (44\%)" [4]. Undoubtedly, these impairments and individual experiences can impact the possibility of returning to work after a stroke. However, the possibility of returning to work also depends on social factors outside the individual $[5,6]$. Therefore, stroke as a disability should be understood as the 
intersection between body, identity, culture, and structure [7], rather than only an impairment or illness.

This article presents some of the findings of a Swedish dissertation (Stories About Stroke and Working Life [8]), and it draws from the same empirical material, which consists of in-depth interviews with persons who have had a stroke and with professionals and civil servants within different welfare organizations. Here, however, the findings will be placed within the context of the changes in the Swedish welfare system.

Although the interviewees in this study used the discourses of employability, workability, and normality, institutional practices differed between organizations - thereby filling these discourses with different meanings. Such discrepancies make it more difficult for persons who have had a stroke in their working age (18-65) to return to the labor market even though they, along with the professionals and civil servants, share the same goal - a return to working life.

\subsection{Earlier research on stroke and working life}

Medical research on stroke aims extensively to prevent, to discover, and to cure [9]. Moreover, as stroke is more common amongst the elderly, most research focuses on persons aged 65 and older. However, research on what a stroke can imply for the everyday lives 
of people of working age is scarce $[10,11]$. Studies on stroke and working life within the Swedish context show that rehabilitation of younger persons who were still working prior to their stroke may require different approaches than those used with older persons due to different life-situations $[3,8,12]$. Hofgren, Esbjörnsson, and Sunnerhagen [13] suggest, for example, that research and clinical work should evaluate fatigue and "abilities, such as affect expression and perception, or executive functions" [13] closer as these are factors often mentioned by individuals as important for their return to work.

The few studies conducted within social sciences on stroke have focused on issues of importance for persons that have had a stroke, their relatives, and their careers [14-17]. Importantly, the perspective of this study differs from such studies as the aim of its analysis is to show how the individual's experiences are connected to and affected by institutional processes and discourses in the welfare organizations. Methodologically, the study is inspired by institutional ethnography, in which a central understanding is that ruling is conducted and made possible in the meeting and relation between individuals and institutional processes [18].

In order to present a background to the findings discussed in this article, overarching changes since the 1990s in the Swedish 
welfare state and labor market will be presented - including the changes to a more neoliberal state, the changing meaning of the work strategy principle, ${ }^{1}$ and the launching of the discourse on employability.

\subsection{The work strategy in Sweden and the change of the Swedish} welfare state in a global context

The conditions for individuals with disabilities to participate in working life or return to work after illness are related to global changes both in the labor market and in working life, as well as changes in the Swedish social welfare system. Larsson, Letell, and Thörn [20] suggest that neoliberal influences - such as marketization, privatization, and deregulation - are recent changes in Sweden that should be seen as having reconfigured the Swedish welfare state, rather than having replaced it with a neoliberal state [20]. New forms of organization of work and production, technical innovation, and increased competition on a global market are other changes that have impacted the labor market over the last two decades [21]. During this period in Sweden, just as in many other countries, flexible and temporary employment have become the norm instead of permanent, life-long, and full-time employment [22]. These changes in the labor market, together with ideological

\footnotetext{
${ }^{1}$ Here the term work strategy is used to refer to arbetslinjen. Others have also translated it with the term workline [19].
} 
changes, have also had an effect on the Swedish welfare system [23]. One part of this system, the social health insurance, plays a central role in the case of illness and disability during working life. Being general rather than connected to the individual's position in the labor market, the health insurance in Sweden differs from most other countries [24]. In Sweden, the rights to social insurance rest upon a universal welfare model based on citizenship. Underlying the Swedish social insurance system is the work strategy principle [23-28], which could be generally explained as a social norm where citizens are supposed to find ways to support themselves; nevertheless, the way it has been reflected in social policy has differed historically $[23,24]$. Junestav [27] has identified three dominant perspectives regarding work strategy: 1) the control and discipline perspective, where the emphasis lies on the individual's responsibility to care financially for himself/herself and contribute to the development of society; 2) the self-help and fostering perspective, where the state encourages individuals to care for themselves financially; and 3) the rights perspective, which frames paid work as the tool for giving all citizens better life chances. This perspective emphasizes the state's responsibility to give the individuals opportunities for paid work. According to Junestav, from the 1980s and onward, the control and discipline perspective where focus is put on individuals' responsibilities to support 
themselves and participate in the development of society - has dominated [27]. Researchers have also argued that this come-back of the control and discipline perspective in the work strategy should be understood in the context of growing state financial problems. The view on long-term sick leave, work injuries, and early retirement in combination with increased unemployment in the 1990s replaced an earlier focus on rights to employment with a focus on individuals who receive different forms of support from the state [29]. The discourse of employability, which was launched in the same period as a consequence of Sweden joining the European Union in 1995 [30], fits very well into this understanding of the individual's responsibility for having employment. Today, employability is defined as an individual's preparation for impending working life and capacity to handle and keep his/her work, as well as his/hers continued career development and possibilities for mobility on the labor market [31].

Here, it is being argued that these changes and neoliberal influences in the Swedish welfare state can be found in the institutional practices of the welfare organizations and, as such, that they affect persons who become ill or disabled when still participating in the workforce. 


\section{Method}

The following presentation is based on a study using semistructured, in-depth interviews with persons who have had a stroke and with professionals and civil servants within welfare organizations. Ten persons who suffered a stroke were interviewed. Participants were recruited through an advertisement placed in the Swedish National Stroke Association magazine (StrokeKontakt). In addition, letters were sent to those registered with the National Stroke Register as having a history of stroke. The criteria for participating in the study were being between the ages of 18 and 65 years, having had a stroke at least one year prior to the study, and being able to speak Swedish. Subsequently, 10 participants were interviewed: six men and four women between 45 and 62 years of age. Participants had different forms of employment, representing the private (three participants) and the public sectors (four participants) in small and large organizations, while three had been self-employed. Four participants returned to work, either to their previous position or to new employment, while six had not returned to work. For the demographics of these participants, see Table 1.

Additionally, a total of ten other interviews were completed: six professionals from different health care institutions, two civil servants from the Swedish Public Employment Service, and two from the Social Insurance Agency. The interviewed civil servants 
from the Social Insurance Agency were administrators. From the Employment Service, an employment officer and a consultant specialized in finding work for persons with disabilities were interviewed. The health care professionals included two nurses at a hospital as well as one nurse, two physiotherapists, and one occupational therapist from a daytime rehabilitating center that targeted persons of working age who have had a stroke. These professionals were interviewed for their experience with rehabilitation and for their focus on functional ability and daily life - a focus that separates them slightly from doctors, who instead focus on curative and preventive measures. Doctors as advisors and as gatekeepers were also interviewed; however, these interviews are not included in this article.

All the interviews were conducted on a one-to-one basis, except in one case where two nurses were interviewed together. The author of this article oversaw all interviews, which had an informal character. The interviews with the professionals and civil servants (here referred to as extra-local informants) concentrated on the institutional practices connected to their professional role and their organizations. The interviews lasted between 40 and 80 minutes, and a semi-structured interview guide was used. The questions to the participants who had a 
stroke were ordered according to the following themes: the stroke, today, and the return to work. The themes of the questions to the professionals and civil servants were as follows: their work tasks and areas of responsibility, the meaning of stroke, and space for action (for the specific interview questions, see Appendix I).

Interviews were taped and transcribed verbatim. A thematic analysis was conducted focusing on experiences, discourses, and practices concerning stroke and return to work. Moreover, the analysis emphasized how institutional practices corresponded (or did not correspond) between the different organizations, or with the experiences of the participants who had a stroke. This approach was inspired by institutional ethnography, in which "difference in perspective and experience are central to discovering how people are active in producing" [18] and reproducing institutional processes. This article will focus on such differing perspectives between different organizations and the experiences of the participants who have had a stroke.

Due to the limited number of respondents, the results cannot be seen as statistically generalizable. However, the approach where different perspectives on return to work after a stroke have been compared enables an in-depth and complex understanding of this phenomenon. 


\section{Results}

\subsection{The (im)possibilities of returning to work}

When the participants who have had a stroke talked about their practices and experiences of stroke and paid work, they made use of discourses concerning employability, workability and normality. For example, when describing her possibilities to re-enter the workforce, Kerstin mentioned how her workability was estimated as "non-existent" in a document from the Social Insurance Agency: "I just received these papers saying that I wasn't worth rehabilitating, and I thought I was. I thought the opposite, that certainly there must be something I can do." Kerstin interpreted this assessment to also mean that she would not be able to return to working life:

Kerstin: And the Social Insurance Agency hasn't mentioned anything other than that it wasn't worth rehabilitating me, and that made me really upset [laughs].

Researcher: Was that what you were trying to do? Kerstin: When it comes down to that, yes, if they had had something [a suitable job]; but they 
didn't. So I have to start to accept this. I haven't

still. Not completely. [...].

Researcher: And can you picture yourself

working with something else?

Kerstin: Yes, but I haven't figured out what. I don't have the endurance that is required today anymore. It's gone. That is, I cannot hold a higher tempo or work for longer periods. So I guess it will have to be like this, if I can't find something on my own.

Kerstin made use of the concept workability, which is an institutional category that has to be filled with content and meaning [18], when she reasoned about her own ability to work. For example, Kerstin mentioned how she no longer had the endurance nor the capability to keep up the fast work tempo that is required today.

Kerstin's statement about her chances to return to her earlier employment - her conclusion that she could no longer return to her previous work or former responsibilities - can be interpreted as an echo of the assessment provided by the Social Insurance Agency which estimated her workability as "non-existent". In addition, Kerstin could not think of other jobs to apply for. 
At the same time, Kerstin questioned the Social Insurance Agency's assessment that stated that her workability was nonexistent, being only 50 years of age at the time of her stroke: "In the middle of life [...] society ought to spend money on rehabilitating me," she said (interview with Kerstin). When Kerstin referred to the written assessment of her work ability from the Social Insurance Agency, she talked of the work strategy as a social contract between society and citizens meaning that with retirement age being 65 in Sweden at the time she was too young not to be contributing to the workforce. This social contract also involves society having a responsibility to try and help her back onto the labor market. This understanding of the work strategy corresponds with the rights perspective rather than the control and discipline perspective presented earlier [28].

Kerstin's narrative provides a personal perspective and experience of no longer living up to normality, namely, supporting oneself, because she no longer had paid employment. According to Priestly [7], being financially independent and participating in production are central features for the norm of what it means to be an adult in Western societies

Several of the participants, who all were over 45 years of age, saw their age, rather than their stroke, as the major cause to why employers saw them as unemployable. Tommy thought his age (53 
years) lowered his chances of getting a new job: "No, I see very small chances. I tried to get back to work again, but I am 53 years old and have been on $25 \%$ sick leave for five years" (interview with Tommy). By referring to new norms and demands in the work place today, the participants described their inability to work as partly outside themselves and the stroke; it is working life that has changed thereby hindering them from living up to "normality".

However, when talking about the changes after their stroke, most of the informants used a biomedical discourse, focusing on their inabilities to concentrate and their extreme fatigue [4] as obstacles to ever working again. Karin described her extreme fatigue as follows: "A meltdown in my brain. The defense comes first from the muscles. Then I get anxiety. Then I just fall asleep" (interview with Karin). Some of the participants talked about the plasticity of the brain, that is, a brain injury, such as a stroke, can heal with time and rehabilitation [34]: "So I said to the doctor, 'I don't think you are up to date with stroke rehabilitation. I have read that the brain has great plasticity; and if rehabilitation is used early on, positive results can be achieved"' (interview with Gösta). By making use of the term "plasticity" from the biomedical discourse, Gösta questioned the institutional practices within health care. Even if only Gösta and Kerstin used the actual term plasticity, other participants also gave concrete examples of how their impairments had become 
better with time. Despite using physical achievements as signs of their improvement, what really troubled the participants were their hidden disabilities, such as extreme fatigue, depression, and concentration problems:

The change mentally has nothing to do with the intellect. And the neurologist tested that. Because I felt like... what the hell is wrong? [...] It's difficult to have changed. You're not the same anymore. But what is different? (interview with Bengt).

All of the informants who had a stroke said they needed more rehabilitation than they had got. Some had paid to go to private rehabilitation centers, but several said they could not afford either rehabilitation or therapy despite feeling the need for it.

The analysis of the participants' interviews shows that having a stroke involved not only a physical and cognitive change but also a move from economic independence to economic dependence. Furthermore, the participants' experiences of stroke and working life point to some of the institutional processes that are produced and reproduced in welfare organizations.

\subsection{Institutional practices and the different welfare organizations}


In the case of sickness or disability for both employees and employers, laws exist that stipulate different actors' responsibilities. There is also a rehabilitation chain that organizes the practices and progression of actions for the different actors involved - the employer, the Social Insurance Agency, and the Employment Service, and sometimes the occupational health care and it dictates the times they should be active. The first welfare organization a person who has had a stroke comes in contact with is a doctor from the health care. This doctor evaluates the workability of the person. The civil servants at the Social Insurance Agency make their decisions concerning a person's right to social insurance benefits based on the doctor's evaluation of this person's workability. However, when moving the analysis to the extra local informants - such as civil servants from the Employment Service, civil servants from the Social Insurance Agency, and professionals from the health care - it became clear that rather than forming a neat chain of actions, practices were at times in disagreement with each other. As will be elaborated on in the following, the professionals and civil servants both referred to and used discourses on employability and work ability in ways that differed, despite sharing the common goal of assisting the individual's return to the workforce. 


\subsection{Practices and discourses within the health care}

As with the participants having had a stroke, the interviewed health care professionals referred to the biomedical discourse on the brain's plasticity. They also talked about the persons' attempts to return to work as a process that often took a long time and involved other job assignments and part-time work. Several of the professionals problematized the notion of many persons having had a stroke wanted to return to work as soon as possible, as this meant neglecting the healing process and saw it as a problem that many of the persons who had had a stroke wanted to go back to work as soon as possible, thereby neglecting the time it can take and the physiotherapy needed to improve their impairments. Where physiotherapy is seen as the best way to return to working life suggests that these professionals within the health care system make use of a biomedical understanding. However, there are examples contrary to this. For instance, one occupational therapist reported that her point of departure was what the person having had a stroke considered to be important. Putting the individual at the center of the rehabilitation process could be understood as a holistic approach [36]. However, such an approach might conflict with a biomedical perspective, for example, when a person having had a stroke wishes to pursue possibilities to return to work, but the professional suggests that physiotherapy is the only viable 
alternative. In the interviews with different professionals within the Health Care organizations, other practices also became visible. In one of the interviews, a nurse informed how she used to encourage persons having had a stroke not to reflect upon what they had been able to do and what their lives looked like before their stroke.

Rather, she encouraged them to compare their current situation and abilities to how they were directly after the stroke. Similarly, the occupational therapist described the person's life before and after a stroke:

The aim of all my training is that they [persons having had a stroke] should become independent, as much as possible, and to return to the life they had; otherwise they have to try adapt to the life they have now. (Interviewing with occupational therapist)

Her aim can be understood as being influenced by an institutional text that guides the practices within stroke rehabilitation: the Helsingborg Declaration, where independence is one of the main goals. While some of the practices of health care professionals and rehabilitation sought to bring the persons having had a stroke closer to their former lives, others aimed at providing them with a new set of goals in line with the conditions of their bodies after their stroke. In their encounters with institutional practices, persons having had 
a stroke are taught a new normality through being encouraged to set new goals and not make comparisons with life before their stroke [37].

The health care professionals gave examples that exemplified how they were relatively free in how they worked. However, they all identified the problematic shortage of psychologists and neuropsychologists in the health care system. They also mentioned the lack of resources committed to these professions as being another problem. This made it difficult for them to attend to impairments such as extreme tiredness and depression, which are common for persons of working age who have had a stroke. Unless these problems were addressed, there was little the professionals could do to better the situation. Prioritizing economic factors puts the physical body and visible disabilities first - thereby neglecting the psychological and cognitive problems that were identified as the most urgent ones, both by the participants who had had a stroke and by the extra local informants.

The interviewed health care professionals shared an understanding that normality meant participating in working life. But rather than making use of the discourse on employability, they referred to independence and physical autonomy as means to enable work ability. 


\subsection{Practices and discourses within the Social Insurance Agency}

Both civil servants from the Insurance Office described their professional role as assessing workability and deciding on the right to social insurance benefits due to illness, as well as coordinating a rehabilitation plan that the person who has had a stroke, the employer, and the health care system could agree upon. They also mentioned that another task of the Social Insurance Agency is to see to the interests of its clients [24]. The assessment of workability is based on the medical evaluation from the patient's doctor, and the compensation rate is adapted to the assessed workability of the individual [38]. Within the Social Insurance Agency, workability is assessed in principle - meaning that workability is evaluated in relation to a fictive labor market [39]. This does not mean that civil servants from the Social Insurance Agency are unaware of factors outside the individual, only that the expectation is that they, in their professional role, should not take this into account when making a decision on a person's workability. When describing this process, one of the civil servants said that a person's right to social insurance benefits should be understood as the same as the right to compensation from "any other insurance company" (interview with civil servant). This comparison of a welfare organization to a private company can be understood in the light of the move to a more neoliberal welfare system [20]. Further, it enabled the civil 
servant to distance herself from the persons she met. The consequence of such an understanding is that the holistic approach strived for within health care disappeared in the institutional processes of the Social Insurance Agency. This was an important difference between the practices in this organization compared to those in health care.

Another difference between the practices within health care and the Social Insurance Agency was the aspect of time. Time and the plasticity of the brain that the health care professionals as well as Kerstin and Gösta referred to as creating a possibility to get better, and perhaps even get back to work in due time, were, however, seen as problematic by the civil servants working within the Social Insurance Agency. One civil servant voiced his concern as follows:

I feel this is where I, in my professional role, clash with curators, physical therapists, and doctors working with this kind of patient - brain damaged, patients with MS, stroke patients as well - where they say 'this will have to take time, we'll have to wait and see....' That doesn't fit the social insurance system we have, and it is my job to put my foot down, [and ask] 'can they or can't they?' If 
the answer of the question is 'we don't know,' well then we are forced to move on in order to find out. (Interview with civil servant)

"To wait and see," as the civil servant described the doctors" practice, takes time and does not correspond with the new and stricter rules from 2008 that regulate the right to social insurance on sick leave.

Yet another tension between the health care professionals and the civil servants from the Social Insurance Agency was their different views on part-time work: ${ }^{2}$ Where the health care professionals mentioned that a part time return to work was a good solution for many inflicted by a stroke, part-time work was, instead, articulated as a problem by the civil servants. Framing a combination of part-time sick benefit and part-time paid work as a problem can be explained by the Social Insurance Agency's organizational goal: to make individuals support themselves.

Just as the view on part-time work differed between the organizations in this study, the discourse on employability was used in opposite ways by the participants who had had a stroke and by the civil servants at the Social Insurance

\footnotetext{
${ }^{2}$ A person who has the right to social insurance benefits can be on sick-leave part time, either 75,50 , or $25 \%$.
} 
Agency. While several of the participants said that employers were hesitant to employ them because of their age, life-long learning was emphasized as something positive and as means to come back to work by the civil servants. For example, one of them said:

Just because a person has worked within one profession for some years, it doesn't have to mean people would or should continue within the same profession their whole life. (Interview with civil servant)

The discourse on employability that the civil servant used here can be understood as supporting a shift from know-how to learn-how. Though education and competence are important factors for the employability of an individual, studies have shown that health and workability are as important [31].

\subsection{Practices and discourses in the Employment Service}

If a person is considered as having workability - but not in his or her current employment, even if adaptations are made (in working hours or the work environment or tasks) and no other job 
assignments are available at the work place - then the person gets transferred from the Social Insurance Agency to the Employment Service. Whereas workability was assessed in principle in the practices of the Social Insurance Agency, the Employment Service's assessments on workability considers "the conditions for a real existent employment," to quote Jacobsson and Seing [39]. This can explain why the civil servants who were interviewed and who worked with IPS (Individual Placement and Support) in the Employment Service had a much broader perspective on what workability meant compared to the civil servants from the Social Insurance Agency. For example, one of the civil servants from the Employment Service who worked as a SIUS-consultant (Special Introduction and Follow Up Support) mentioned "endurance [...] and the ability to participate and communicate with others in the workplace" when asked to define workability (interview with SIUS-consultant). When referring to her own role, she described her work practices as depending on the conditions of social structures such as the labor market and legislation as well as the attitudes of the employers. The aim of her practices was to come close to the person she is trying to help back to the labor market and to take into consideration the everyday life of the person who has had a stroke rather than to distance herself from it. This is a 
different institutional approach than the one used by the Social Insurance Agency.

As with the participants having had a stroke, the professionals and the civil servants mentioned the time it might take to recover from a stroke. One of the Employment Service workers additionally saw the recovery time as a factor that made stroke a disability that "does not fit the system" (interview with civil servant at the Social Insurance Service). With that she meant that since some labor market measures available in their organization were aimed only at persons who could be expected to return to work within one year, and since it is difficult to assess if workability will exist a year after a stroke, persons who have had a stroke became excluded from such projects.

\subsection{Discussion}

The focus of the institutional practices in the health care system, in the Social Insurance Agency, and in the Employment Service differed. The health care professionals' practices focused on both physical condition and on the effort to make persons who have had a stroke independent in their daily life as a way back to normality. This often meant considering the person's everyday life and working with a 
holistic perspective. However, as shown in the analysis, the goals that the persons having had a stroke formulated were sometimes considered too far reaching. Consequently, part of the process was to make the person change his or her expectations of what the rehabilitation would accomplish. The practices of the Social Insurance Agency were somewhat contradictory since the agency's role was to estimate a person's workability, to make a decision about his/her right to social insurance benefits, and at the same time, to see to the interests of the individual. Their assessments were based on medical evaluations only, which prevented them from taking social factors into consideration. This resulted in the civil servants having to distance themselves from the everyday lives of the people who had had a stroke, which is in contrast to the civil servants at the Employment Service. Still, opportunities for work placement were dependent on the available resources in the organization and available work on the labor market, thereby making their acting space limited.

This article contributes to an understanding of social barriers confronting persons attempting to return to work after a stroke. It establishes that such attempts are influenced by contradicting and conflicting institutional practices and discourses in the different organizations, even though the work strategy is the 
underlying issue for all of the studied organizations. The small number of informants limits the results of this study. Moreover, the perspectives of the employers are missing. Further studies are needed regarding how employers handle employees who have neurological and other impairments that fluctuate in the rehabilitation processes back to work. Another limitation is that the author carried out interviews and the analysis, which can create bias.

\section{Conclusion}

The individuals who had had a stroke, the rehabilitation professionals, and the civil servants shared a common goal: returning the person who has had a stroke to working life and finding the solutions for this to become a reality. The interviews with the officials made it clear that a return to work was considered the best alternative. However, the participants' possibilities to return to work after their strokes were, in several ways, limited by institutional discourses and practices. The analysis made visible how the concept of workability and striving for normality meant different things for the stroke participants and for the officials, depending on the organization at which they worked. Another central aspect in the interviews, both with the participants and with the professionals and civil servants, was how work was seen as 
equivalent with normality and with independence. In Sweden, different social policies have been put into practice since the 1920s to get the unemployed into work; however, the underlying principle has always been, and still is, the individual's obligation to provide for oneself [25]. As initially described, the work strategy principle has moved into a more neoliberal direction where the control- and discipline perspective is more prominent.

This analysis contributes to the understanding of how this development of the work strategy can be seen in institutional processes within welfare organizations. Officials' practices and the discourses they use are all focused on a return to work for the persons who have had a stroke. Even though the interviewed officials - much like the participants who had had a stroke, talked about social factors and saw them as having an impact on the possibility to return to work, their practices focused on the individual. Such a focus strengthens the understanding of normality as being physically and financially autonomous, employable, and working [7].

One problem with the discourse on employability is the notion that anyone can become employable, for example, by being flexible. Such a presumption places the responsibility of going back to work on the individual. It also makes employers' demands invisible; the demand to act employable as defined by employers and social policy 
might make people who are unable to live up to this standard abandon working life - even when they are able to work for pay [40].

\section{Acknowledgements}

[Edited for the review process]

\section{References}

[1] M. Vestling, M, Ramel E, Iwarsson S. Quality of life after stroke: well being, life satisfaction and subjective aspects of work. Scandinavian Journal of Occupational Therapy. 2005; 12(2): 89-95.

[2] Medin J, Nordlund A, Ekberg K. Increasing stroke incidence in Sweden between 1989 and 2000 among persons aged 30 to 65 years: Evidence from the Swedish hospital discharge register. Stroke. 2004; 35:1047-1051.

[3] Medin J. Stroke among people of working age: from a public health and working life perspective [dissertation]. Linköping: Univ.; 2006.

[4] Wang, Y. Kapellusch, J, Gargc, A. Important factors influencing the return to work after stroke. Work. 2014; 47(4): 553559. 
[5] Saeki, S, Hachisuka, K. The association between stroke location and return to work after first stroke, Journal of Stroke and Cerebrovascular Diseases. 2004; 13(4)160-163.

[6] Medin, J. Ekberg, K. Nordlund, A. Eklund, J. Organisational change, job strain and increased risk of stroke? A pilot study. Work, 2008; 31(4): 443-449.

[7] Priestly, M. Disability: a life course approach. Cambridge, UK. Polity; 2003.

[8] Norstedt M. Stories about Stroke and Working Life. Discovering Ruling Relations. Lund: Lund university, Department of Sociology; 2011.

[9] Hamilton I. Leva med stroke: lära av erfarenheter [dissertation]. Malmö: Institutionen för pedagogik, Lärarhögsk.; 2000.

[10] Gilworth G, Phil M, Cert A, Sansam KA, Kent RM. Personal experiences of returning to work following stroke: an exploratory study. Work, 2009; 34(1): 95-103.

[11] Treger, I. Shames, J. Giaquinto, S. Ring, H. Return to work in stroke patients. Disability and Rehabilitation: An International, Multidisciplinary Journal. 2007; 29(17): 1397-1403.

[12] Röding J. Stroke in the younger: self-reported impact on work situation, cognitive function, physical function and life satisfaction: a national survey [dissertation]. Umeå: Umeå University; 2009. 
[13] Hofgren, C. Esbjörnsson, E, Sunnerhagen, KS. Return to work after acquired brain injury: facilitators and hindrances observed in a sub-acute rehabilitation setting. Work. 2010; 36(4): 431-439.

[14] Doolittle, N. The Experience of Recovery Following a lacunar Stroke. Rehabilitation Nursing. 1992; 17(3):122-125.

[15] Faircloth, C. A, Boylstein, C, Rittman, M., Young, M. E, Gubrium, J. F. Sudden Illness and Biographical Flow in Narratives of Stroke Recovery. Sociology of Health and Illness. 2004; 26(2), 242-261.

[16] Kaufman, S. Illness, Biography, and the Interpretation of Self Following a Stroke. Journal of Aging Studies. 1988; 2(3):217-227. [17] Pound, P, Gomertz, P, Shah, E. A patient-centred study of the consequences of stroke. Clinical Rehabilitation. 1998; 12(4):338347.

[18] Smith, D. E. Institutional ethnography: a sociology for people. Walnut Creek, CA: AltaMira Press; 2005.

[19] Bergmark, Å. Activated to Work? Activation Policies in Sween in the 1990s. La Revue Française des Affaires Sociales. 2003; 4(4):291-306.

[20] Larsson B, Letell M, Thörn H, editors. Transformations of the Swedish welfare state: from social engineering to governance?. New York: Palgrave Macmillan; 2012. 
[21] Beck, U. Brave new world of work. Cambridge: Polity Press; 2008.

[22] Thedvall, R. “'Do it yourself”: Making up the self-employed individual in the Swedish Public Employment Service. In: Garsten, C, Jacobsson, K, editors. Learning to be employable: New agendas on work, responsibility and learning in a globalizing world.

Basingstoke: Palgrave Macmillan; 2004.

[23] Lindqvist, R, Marklund, S. Arbetslinjen i socialpolitiken. In: Marklund, S, editor. Rehabilitering i ett samhällsperspektiv. Lund: Studentlitteratur; 1995.

[24] Ståhl, C, Seing, I. Arbetslinjer och arbetsförmåga. In: Ekberg, K, editor. Den relativa arbetsförmågan, Lund: Studentlitteratur; 2014.

[25] Eriksson L. Arbete till varje pris [Elektronic resource] : arbetslinjen i 1920-talets arbetslöshetspolitik [dissertation]. Stockholm: Almqvist \& Wiksell International; 2004. [cited 2015 Feb 17]Available from: http://urn.kb.se/resolve?urn=urn:nbn:se:su:diva-210. [26] Hetzler, A. Rehabilitering och de långtidssjukskrivna. In: Lindqvist, R, Hetzler, A, editors. Rehabilitering och välfärdspolitik. Lund: Studentlitteratur; 2004, p. 79-95. 
[27] Junestav M. Arbetslinjer i svensk socialpolitisk debatt och lagstiftning 1930-2001 [dissertation]. Uppsala: Acta Universitatis Upsaliensis; 2004.

[28] Lindqvist, R, Hetzler, A, editors. Rehabilitering och välfärdspolitik. Lund: Studentlitteratur; 2004.

[29] Lindqvist, R. Att sätta gränser: organisationer och reformer arbetsrehabilitering. Umeå: Boréa; 2000.

[30] Bengtsson, M, Berglund, T. Labor market policies in transition: from social engineering to standby-ability. In: Larsson B, Letell M, Thörn H, editors. Transformations of the Swedish welfare state: from social engineering to governance?. New York: Palgrave Macmillan; 2012: p. 86-103.

[31] Nilsson, S, Ekberg, K. Förutsättningar för arbetsförmåga och anställningsbarhet på arbetsmarknaden. In: Ekberg, K, editor. Den relativa arbetsförmågan. Teoretiska och praktiska perspektiv. Lund: Studentlitteratur; 2014; 111-126.

[32] Försäkringskassan [homepage on the Internet] [cited on the 12 June 2016]. Available from www.forsakringskassan.se/wps/wcm/connect/ce6af707-5612-4a3cbafd$\underline{\text { 3b9f340e3ccb/sjukpenning_tidsbegransad_eng.pdf?MOD=AJPER }}$ $\underline{\mathrm{ES}}$ 
[33] Holmqvist, M. Corporate social responsibility as corporate social control: The case of work-site health promotion.

Scandinavian Journal of Management. 2008; 25(1):68-72.

[34] BrainFacts.org [homepage on the Internet]. What is brain plasticity, and does it have potential to help alleviate psychiatric or degenerative brain disorder? [updated 2012 April 23; cited on 13 Feb 2015]. Available from: http://www.brainfacts.org/aboutneuroscience/ask-an-expert/articles/2012/what-is-brain-plasticity [35] WHO [homepage on the Internet]. Helsingborg Declaration 2006 on European Stroke Strategies. WHO; 2005 [cited 2015 Feb 17]. Available from: http://apps.who.int/iris/bitstream/10665/107780/1/E89242.pdf?ua= 1 [36] Leach, E, Cornwell, P, Fleming, J, Haines, T. Patient centered goal-setting in a subacute rehabilitation setting. Disability and Rehabilitation, 2010; 32(2), p.159-172

[37] Sandell K. Att (åter)skapa "det normala": bröstoperationer och brännskador i plastikkirurgisk praktik [dissertation]. Lund: Arkiv; 2001.

[38] Björnberg, U. Social policy reforms in Sweden: new perspectives on rights and obligations. In: Larsson, B, Letell, M, Thörn, H, editors. Transformations of the Swedish welfare state: 
from social engineering to governance?. Basingstoke: Palgrave Macmillan; 2012: p.71-85.

[39] Jacobsson, K, Seing, I. En möjliggörande arbetsmarknadspolitik? Arbetsförmedlingens utredning och klassificering av klienters arbetsförmåga, anställbarhet och funktionshinder. Arbetsmarknad och Arbetsliv, 2013;19(1), p. 9-24. [40] Härenstam, A. Riskfyllda förändringar i arbetslivet och strategier för åtgärder. In: Jenner, H, Svensson, I, editors. Perspektiv på utbrändhet: om orsaker och motkrafter. Stockholm: Gothia; 2003: p. $52-75$. 